УДК 618.3-06:618.33/.38-073.432.19

DOI 10.11603/24116-4944.2021.1.12369

๑А. Я. Сенчук, В. І. Чермак, А. В. Заболотна, Т. П. Андрійчук

ПВНЗ «Київсъкий медичний університет»

\title{
РЕЗУЛЬТАТИ ЕХОГРАФІЇ ФЕТОПЛАЦЕНТАРНОГО КОМПЛЕКСУ У ВАГІТНИХ ІЗ УСКЛАДНЕНИМ ПЕРЕБІГОМ ГЕСТАЦІї
}

Мета дослідження - вивчення за допомогою ехографії особливостей фетоплацентарного комплексу (ФПК) у вагітних із запальними захворюваннями нирок, анемією та гіпертензивними розладами.

Матеріали та методи. Для комплексного вивчення стану ФПК у жінок групи високого ризику розвитку плацентарної диссункції (ПД) вагітні були поділені на групи. До основної групи увійшли 150 вагітних, із них у 50 жінок вагітність ускладнилася залізодефіцитною анемією легкого та середнього ступенів тяжкості (I група), 50 жінок страждали від запальних захворювань нирок (гестаційний пієлонесрит, загострення хронічного пієлонефриту під час вагітності) (II група), у 50 було виявлено пізній гестоз (ПГ) у вигляді прееклампсії легкого та середнього ступенів тяжкості (III група). До IV групи зараховано 50 здорових вагітних (контрольна група). Показники стану ФПК у здорових вагітних та вагітних групи високого ризику розвитку ПД визначали за допомогою апарата GE Voluson S10 (США).

Результати дослідження та їх обговогення. Показники середнього бала оцінки стану ФПК, за класифікацією І. С. Сидорової, І. О. Макарова [1], свідчать про розвиток компенсованої фрорми ФПК у жінок, вагітність яких ускладнюється запальними захворюваннями нирок, та тенденцію до субкомпенсації у разі ускладнення вагітності ПГ. Визначені зміни не $€$ діагнозом, це маркери динамічного стану, і ці показники можуть змінюватись у той чи інший бік у разі пд. За фрормування і прогресування ФПН показники можуть різко змінюватись у негативний бік і мати незворотний характер. Отже, аналізуючи дані дослідження стану ФПК за методикою ехографії, можна простежити наявність прогресивного погіршення стану ФПК у жінок групи високого ризику розвитку ПД.

Висновки. Категорія пацієнток із виявленими ехографічними ознаками порушень ФПК потребує ретельнішого спостереження і прийняття рішень залежно від терміну вагітності і прогресування ознак ФПН.

Ключові слова: вагітність; ехографія; пієлонесрит; анемія; прееклампсія; плацентарна диссункція.

РЕЗУЛЬТАТЫ ЭХОГРАФИИ ФЕТОПЛАЦЕНТАРНОГО КОМПЛЕКСА У БЕРЕМЕННЫХ С ОСЛОЖНЕННЫМ ТЕЧЕНИЕМ
ГЕСТАЦИИ

Цель исследования - изучение с помощью эхографии особенностей фретоплацентарного

Материалы и методы. Для комплексного изучения состояния ФПК у женщин группы высокого риска развития плацентарной диссункции (ПД) беременные были поделены на группы. В основную группу вошли 150 беременных, из них у 50 женщин беременность осложнилась железодесицитной анемией легкой и средней степени тяжести (I группа), 50 женщин имели воспалительные заболевания почек (гестационный пиелонефрит, обострение хронического пиелонесрита во время беременности) (II группа), у 50 было обнаружено поздний гестоз (ПГ) в виде преэклампсии легкой и средней степеней тяжести (III группа). K IV группе отнесены 50 здоровых беременных (контрольная группа). Показатели состояния ФПК у здоровых беременных и беременных группы высокого риска развития ПД определяли с помощью аппарата GE Voluson S10 (CШA).

Результаты исследования и их обсуждение. Показатели среднего балла оценки состояния ФПК, по классификации И. С. Сидоровой, И. А. Макарова [1], свидетельствуют о развитии компенсированной фрормы ФПК у женщин, беременность которых осложняется воспалительными заболеваниями почек, и тенденции к субкомпенсации в случае осложнения беременности ПГ. Данные изменения не являются диагнозом, это маркеры динамического состояния, и эти показатели могут изменяться в ту или иную сторону в случае ПД. В случае фрормирования и прогрессирования ФПН показатели могут резко изменяться в отрицательную сторону и иметь необратимый характер. Итак, анализируя данные исследования состояния ФПК по методике эхографии, можно проследить наличие прогрессивного ухудшения состояния ФПК у женщин группы высокого риска развития ПД.

Выводы. Категория пациенток с выявленными эхограсическими признаками нарушений ФПК требует тщательного наблюдения и принятия решений в зависимости от срока беременности и прогрессирования признаков ФПН.

Ключевые слова: беременность; эхография; пиелонефрит; анемия; преэклампсия; плацентарная диссрункция.

RESULTS OF ULTRASOUND OF THE PHETOPLACENTARY COMPLEX IN PREGNANT WOMEN WITH COMPLICATED GESTATION

The aim of the study - ultrasound study of the features of the fetoplacental complex (FPC) in pregnant women with inflammatory kidney disease, anemia and hypertension.

Materials and Methods. To comprehensively study the state of FPC in women at high risk of placental dysfunction (PD), pregnant women were divided into groups. The main group included 150 pregnant women, of whom 50 women had complicated by iron deficiency anemia of mild and moderate severity (group I), 50 women suffered from inflammatory kidney disease (gestational pyelonephritis, exacerbation of chronic pyelonephritis during pregnancy) (group II), in 50 late gestosis was detected in the form of mild and moderate preeclampsia (group III). Group IV included 50 healthy pregnant women (control group). Indicators of FPC status in healthy pregnant women and pregnant women at high risk of developing PD were determined using the GE Voluson S10 (USA).

Results and Discussion. Indicators of the average score of the assessment of the state of FPC according to the classification by I. S. Sidorova, I. O. Makarov [1] indicate the development of a compensated form of FPC in women whose pregnancy is complicated by inflammatory kidney disease and the tendency to subcompensation in case of complication of late gestosis pregnancy. Certain 
changes are not a diagnosis, they are markers of a dynamic state, and these indicators can change in one direction or another in the case of PD. With the formation and progression of fetoplacental insufficiency indicators can change dramatically in a negative direction and be irreversible. Therefore, analyzing the data of the study of the state of FPC by ultrasound, we can trace the presence of progressive deterioration of the state of FPC in women at high risk of developing PD.

Conclusions. The category of patients with detected ultrasound signs of FPC disorders requires more careful monitoring and decision-making depending on the gestational age and the progression of fetoplacental insufficiency symptoms.

Key words: pregnancy; ultrasound; pyelonephritis; anemia; preeclampsia; placental dysfunction.

ВстУп. Сприятливий перебіг вагітності та її результат залежать від стану здоров'я матері та наявності ускладнень під час гестації. Порушення фрункціонального стану фетоплацентарної системи (ФПС) є головною причиною ускладненого перебігу вагітності та пологів, які також мають несприятливі наслідки для плода і новонародженого [2-5].

Патологічні зміни у системі мати-плацента-плід із самого початку мають фрункціональний і компенсаторний характер. Сучасними методами діагностики ми можемо визначити наявність ПД, яка проявляється зменшенням матково-плацентарного і фетоплацентарного кровообігу, що призводить до зниження постачання артеріальної крові до плаценти і плода, порушення газообміну i метаболічних процесів, зниження синтезу і дисбалансу гормонів плаценти [6-9].

У випадку тривалої дії несприятливих оракторів (погіршення перебігу екстрагенітальної патології, ускладнення вагітності: анемія, гіпертензія і прееклампсія та ін.), несвоєчасної діагностики і лікування ПД відбувається виснаження і пригнічення компенсаторно-пристосувальних реакцій, порушення процесів дозрівання плаценти, уповільнюється ріст і розвиток плода [6, 7]. Отже, фрормуються морфрофункціональні зміни, і цей стан визначається терміном «фетоплацентарна недостатність» (ФПН). На цьому етапі патологічні зміни мають вже незворотний (патоморфологічний) характер і призводять до ускладненого перебігу вагітності та пологів (загроза переривання вагітності і передчасних пологів, гестоз, аномалії пологової діяльності, передчасне відшарування плаценти, дистрес плода тощо), несприятливо впливають на перинатальну захворюваність і смертність [2, 7, 10].

Все це вказує на необхідність динамічного спостереження за станом матері і плода за наявності у вагітної екстрагенітальної патології і фракторів високого ризику перинатальної захворюваності і смертності [11]. Найкращим шляхом вирішення цього питання є використання комплексного підходу до вивчення єдиної системи матиплацента-плід. Тільки на підставі результатів комплексної оцінки стану системи мати-плацента-плід може бути обрана раціональна тактика ведення вагітної, проведена своєчасна патогенетична терапія, обрана правильна тактика розродження і отриманий оптимальний результат пологів для матері та дитини [2, 7, 8].

Сидорова І. С. і Макаров І. О. [1] запропонували бальну шкалу визначення стану ФПК за результатами ехографрічного дослідження (2000). Шкалу використовують для визначення функціонального стану ФПК, виявлення і оцінки тяжкості ФПН та визначення ступеня вираженості його компенсаторних можливостей.

Найчастіше під час вагітності ми натрапляємо на запальні захворювання нирок (33Н) [12], ускладнення гестації [13], анемію [14] та гіпертензивні розлади [15]. Перераховані патології належать до фракторів ризику розвитку ПД і ФПН.

МЕТА ДОСЛІДЖЕННЯ - вивчення За допомогою ехограсрії особливостей ФПК у вагітних із запальними захворюваннями нирок, анемією та гіпертензивними розладами.

МАТЕРІАЛИ ТА МЕТОДИ. ДЛЯ компЛексного вИвчення стану ФПК у жінок групи високого ризику розвитку ПД вагітні були поділені на групи. До основної групи увійшли 150 вагітних, із них у 50 жінок вагітність ускладнилася залізодесріцитною анемією легкого та середнього ступенів тяжкості (І група), 50 жінок страждали від 33Н (гестаційний пієлонефрит, загострення хронічного пієлонесриту під час вагітності) (II група), у 50 було виявлено ПГ у вигляді прееклампсії легкого та середнього ступенів тяжкості (III група). До IV групи зараховано 50 здорових вагітних (контрольна група).

Показники стану ФПК у здорових вагітних та вагітних групи високого ризику розвитку ПН ми визначали за допомогою апарата GE Voluson S10 (США). На підставі результатів ехографрічного дослідження, проведеного в терміни 34-40 тижнів, визначались бали, які заносили до шкали Сидорової І. С., Макарова І. О. (2000) [1]. Перераховані в шкалі показники оцінювали протягом 30 хвилин. Підсумковий індекс в 5 балів свідчив про відсутність ФПН, у 4 бали - про наявність ознак компенсованої форми ФПН, у 3 бали - декомпенсованої та 1 бал - про наявну критичну форму ФПН.

Отримані результати опрацювали методами варіаційної статистики: абсолютні величини - 3 використанням критерію (t) Стьюдента, відносні величини (\%) - непараметричного критерію кутового перетворення (f) Фішера. Рівень ймовірності безпомилкового прогнозу обмежувався t-критерієм, відповідно, $\mathrm{t} \geq 2$ та $\mathrm{P} \geq 95 \%$ або для оцінки ймовірнісних характеристик результатів будь-якого $з$ використаних статистичних методів $0,001<p<0,05$

РЕЗУЛЬТАТИ ДОСЛІДЖЕННЯ ТА ЇХ ОБГОВОРЕННЯ. Фетометричні показники плодів в обстежених вагітних представлені в таблиці 1.

3 таблиці, що ілюструє показники оретометрії в обстежених групах, помітно, що в контрольній групі феетометричні показники всіх плодів відповідають нормативам для відповідного гестаційного терміну, у I групі зареєстровано симетричну фрорму синдрому затримки розвитку плода (СЗРП) у 2-х випадках $((4,0 \pm 2,77) \%)$, у вагітних II групи - в 4-х випадках $((8,0 \pm 3,84) \%)$ спостерігалась асиметрична срорма СЗРП та в 3-х випадках $((6,0 \pm 3,36) \%)$ - симетрична фрорма СЗРП. Значні відхилення показників фретометрії було виявлено у вагітних із ПГ (III група). А саме: у 10 випадках $((20,0 \pm 5,66) \%)$ зареєстровано 
Таблиця 1. Фетометричні показники $(\mathrm{P} \pm \mathrm{m})$

\begin{tabular}{|c|c|c|c|c|c|}
\hline \multirow{2}{*}{ Обстежені групи } & \multirow{2}{*}{ СП } & \multicolumn{4}{|c|}{ Бали } \\
\hline & & 5 & 3 & 1 & 0 \\
\hline $\begin{array}{l}\text { I. Вагітні з анемією, } \\
\mathrm{n}=50\end{array}$ & $\begin{array}{c}\text { абс. } \\
\%\end{array}$ & $\begin{array}{c}48 \\
96,0 \pm 2,77\end{array}$ & 0 & $\begin{array}{c}2 \\
4,0 \pm 2,77\end{array}$ & 0 \\
\hline $\begin{array}{l}\text { II. Вагітні з 33H, } \\
\text { n=50 }\end{array}$ & $\begin{array}{c}\text { aбc. } \\
\%\end{array}$ & $\begin{array}{c}43 \\
86,0 \pm 4,91^{*}\end{array}$ & $\begin{array}{c}4 \\
8,0 \pm 3,84^{\star} \\
\end{array}$ & $\begin{array}{c}3 \\
6,0 \pm 3,36 \\
\end{array}$ & 0 \\
\hline $\begin{array}{l}\text { III. Вагітні з ПГ, } \\
\text { n=50 }\end{array}$ & $\begin{array}{c}\text { aбc. } \\
\%\end{array}$ & $\begin{array}{c}32 \\
64,0 \pm 6,79^{*}\end{array}$ & $\begin{array}{c}10 \\
20,0 \pm 5,66^{*}\end{array}$ & $\begin{array}{c}6 \\
12,0 \pm 4,60^{*}\end{array}$ & $\begin{array}{c}2 \\
4,0 \pm 2,7 \\
\end{array}$ \\
\hline $\begin{array}{l}\text { IV. Контрольна група, } \\
\text { n=50 }\end{array}$ & $\begin{array}{c}\text { aбc. } \\
\%\end{array}$ & $\begin{array}{c}50 \\
100,0\end{array}$ & 0 & 0 & 0 \\
\hline
\end{tabular}

Примітка: * - p<0,05 між показниками контрольної і I, II та III груп.

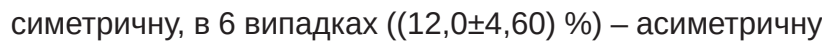
і в 2-х випадках $((4,0 \pm 2,77) \%)$ - змішану фрорму СЗРП.

Показники серцевої діяльності плода (СДП) представлено в таблиці 2.

Отримані результати СДП свідчать про наявність дистресу плодів у вагітних основної групи, яка проявлялася змінами ЧСС від тахікардії з поодинокими та періодичними екстрасистоліями, нестабільної чСС до брадикардії. У вагітних контрольної групи такі зміни СДП не спостерігались.

Вивчаючи показники дихальних рухів плода (ДРП), які також несуть інорормацію про ступінь вираженості ФПН, ми виявили наступні зміни (табл. 3).

У контрольній групі вагітних показники ДРП практично не виходили за межі норми, тоді як в основній групі зареєстровано зміни частоти та тривалості ДРП, у III групі навіть зафріксовано в 1 випадку ДРП за типом gasps. Зниження частоти ДРП, вкорочення їх епізодів та наявність патологічних фрорм свідчать про порушення стану плода і є чутливим індикатором порушення його гомеостазу $[16,17]$.

Показники рухової активності плода (РАП) представлено в таблиці 4.

В основній групі зареєстровано зміни РАП у вигляді зменшення кількості епізодів, хаотичність РАП, відсутність генералізованих рухів та наявність рухів тільки кінцівками. Найяскравіші зміни спостерігалися в групі жінок із ПГ. За даними F. A. Manning et al. [18], виявлені зміни є ознакою порушення стану плода.

Тонус плода (ТП) є також важливим діагностичним критерієм стану ФПК. Показники ТП представлено в таблиці 5.

Показники ТП, за нашими даними, були нормальними у жінок контрольної групи. У 5 випадках $((10,0 \pm 4,24) \%)$

Таблиця 2. Показники серцевої діяльності плода (P士m)

\begin{tabular}{|c|c|c|c|c|c|c|c|}
\hline \multirow{2}{*}{ Обстежені групи } & \multirow{2}{*}{ СП } & \multicolumn{6}{|c|}{ Бали } \\
\hline & & 5 & 4 & 3 & 2 & 1 & 0 \\
\hline $\begin{array}{l}\text { I. Вагітні з анемією, } \\
\mathrm{n}=50\end{array}$ & $\begin{array}{c}\text { абс. } \\
\%\end{array}$ & $\begin{array}{c}39 \\
78,0 \pm 5,86^{*}\end{array}$ & $\begin{array}{c}6 \\
12,0 \pm 4,60 *\end{array}$ & $\begin{array}{c}3 \\
6,0 \pm 3,36\end{array}$ & $\begin{array}{c}2 \\
4,0 \pm 2,77\end{array}$ & 0 & 0 \\
\hline $\begin{array}{l}\text { II. Вагітні з 33H, } \\
n=50\end{array}$ & $\begin{array}{c}\text { абс. } \\
\%\end{array}$ & $\begin{array}{c}41 \\
82,0 \pm 5,43^{*}\end{array}$ & $\begin{array}{c}5 \\
10,0 \pm 4,24^{*}\end{array}$ & $\begin{array}{c}2 \\
4,0 \pm 2,77\end{array}$ & $\begin{array}{c}2 \\
4,0 \pm 2,77\end{array}$ & 0 & 0 \\
\hline $\begin{array}{l}\text { III. Baгітні } 3 \text { ПГ, } \\
\text { n=50 }\end{array}$ & $\begin{array}{c}\text { абс. } \\
\%\end{array}$ & $\begin{array}{c}26 \\
52,0 \pm 7,07^{*}\end{array}$ & $\begin{array}{c}7 \\
14,0 \pm 4,91 *\end{array}$ & $\begin{array}{c}9 \\
18,0 \pm 4,05^{*}\end{array}$ & $\begin{array}{c}4 \\
8,0 \pm 3,84^{*}\end{array}$ & $\begin{array}{c}3 \\
6,0 \pm 3,36\end{array}$ & $\begin{array}{c}1 \\
2,0 \pm 1,41\end{array}$ \\
\hline $\begin{array}{l}\text { IV. KГ, } \\
n=50\end{array}$ & $\begin{array}{c}\text { абс. } \\
\%\end{array}$ & $\begin{array}{c}50 \\
100,0\end{array}$ & 0 & 0 & 0 & 0 & 0 \\
\hline
\end{tabular}

Примітка. * - p<0,05 між показниками контрольної і I, II та III груп.

Таблиця 3. Показники дихальних рухів плода (P士m)

\begin{tabular}{|c|c|c|c|c|c|c|c|}
\hline \multirow{2}{*}{ Обстежені групи } & \multirow{2}{*}{ СП } & \multicolumn{6}{|c|}{ Бали } \\
\hline & & 5 & 4 & 3 & 2 & 1 & 0 \\
\hline $\begin{array}{l}\text { I. Вагітні } з \text { анемією, } \\
\mathrm{n}=50\end{array}$ & $\begin{array}{c}\text { aбc. } \\
\%\end{array}$ & $\begin{array}{c}36 \\
72,0 \pm 6,35^{\star}\end{array}$ & $\begin{array}{c}6 \\
12,0 \pm 4,60^{*}\end{array}$ & $\begin{array}{c}8 \\
16,0 \pm 5,18^{*}\end{array}$ & 0 & 0 & 0 \\
\hline $\begin{array}{l}\text { II. Bariтні з 33H, } \\
\text { n=50 }\end{array}$ & $\begin{array}{c}\text { абс. } \\
\%\end{array}$ & $\begin{array}{c}40 \\
80,0 \pm 6,93^{*}\end{array}$ & $\begin{array}{c}6 \\
12,0 \pm 4,60 *\end{array}$ & $\begin{array}{c}2 \\
4,0 \pm 2,77\end{array}$ & $\begin{array}{c}2 \\
4,0 \pm 2,77\end{array}$ & 0 & 0 \\
\hline $\begin{array}{l}\text { III. Вагітні з ПГ, } \\
\text { n=50 }\end{array}$ & $\begin{array}{c}\text { абс. } \\
\%\end{array}$ & $\begin{array}{c}23 \\
46,0 \pm 5,95^{\star}\end{array}$ & $\begin{array}{c}9 \\
18,0 \pm 4,05^{*}\end{array}$ & $\begin{array}{c}9 \\
18,0 \pm 4,05^{\star}\end{array}$ & $\begin{array}{c}8 \\
16,0 \pm 5,18^{*}\end{array}$ & $\begin{array}{c}1 \\
2,0 \pm 1,41\end{array}$ & 0 \\
\hline $\begin{array}{l}\text { IV. КГ, } \\
\mathrm{n}=50\end{array}$ & $\begin{array}{c}\text { абс. } \\
\%\end{array}$ & $\begin{array}{c}48 \\
96,0 \pm 2,77\end{array}$ & $\begin{array}{c}1 \\
2,0 \pm 1,41\end{array}$ & $\begin{array}{c}1 \\
2,0 \pm 1,41\end{array}$ & 0 & 0 & 0 \\
\hline
\end{tabular}

Примітка: * - p<0,05 між показниками контрольної і I, II та III груп. 
Таблиця 4. Показники рухової активності плода (P士m)

\begin{tabular}{|c|c|c|c|c|c|c|c|}
\hline \multirow{2}{*}{ Обстежені групи } & \multirow{2}{*}{ СП } & \multicolumn{6}{|c|}{ Бали } \\
\hline & & 5 & 4 & 3 & 2 & 1 & 0 \\
\hline $\begin{array}{l}\text { I. Вагітні з анемією, } \\
\mathrm{n}=50\end{array}$ & абс. \% & $\begin{array}{c}37 \\
74,0 \pm 6,83 \text { * }\end{array}$ & $\begin{array}{c}4 \\
8,0 \pm 3,84^{\star \star}\end{array}$ & $\begin{array}{c}3 \\
6,0 \pm 3,36^{* *}\end{array}$ & $\begin{array}{c}6 \\
12,0 \pm 4,60^{*}\end{array}$ & 0 & 0 \\
\hline $\begin{array}{l}\text { II. Вагітні з 33H, } \\
\mathrm{n}=50\end{array}$ & абс. \% & $\begin{array}{c}33 \\
66,0 \pm 6,65 \text { * }\end{array}$ & $\begin{array}{c}6 \\
12,0 \pm 4,60^{*}\end{array}$ & $\begin{array}{c}2 \\
4,0 \pm 2,77^{\star *}\end{array}$ & $\begin{array}{c}9 \\
18,0 \pm 4,05^{*}\end{array}$ & 0 & 0 \\
\hline $\begin{array}{l}\text { III. Вагітні } 3 \text { ПГ, } \\
\text { n=50 }\end{array}$ & абс. \% & $\begin{array}{c}20 \\
40,0 \pm 6,93 \text { * }\end{array}$ & $\begin{array}{c}8 \\
16,0 \pm 5,18^{*}\end{array}$ & $\begin{array}{c}8 \\
16,0 \pm 5,18^{*}\end{array}$ & $\begin{array}{c}12 \\
24,0 \pm 4,60^{*}\end{array}$ & $\begin{array}{c}2 \\
4,0 \pm 2,77^{\star *}\end{array}$ & 0 \\
\hline $\begin{array}{l}\text { IV. KГ, } \\
\mathrm{n}=50\end{array}$ & абс. \% & $\begin{array}{c}49 \\
98,0 \pm 7,07\end{array}$ & $\begin{array}{c}1 \\
2,0 \pm 1,41\end{array}$ & 0 & 0 & 0 & 0 \\
\hline
\end{tabular}

Примітка: * - p<0,05 між показниками контрольної і I, II та III груп.

Таблиця 5. Показники тонусу плода (P士m)

\begin{tabular}{|c|c|c|c|c|}
\hline \multirow{2}{*}{ Обстежені групи } & \multirow{2}{*}{ СП } & \multicolumn{3}{|c|}{ Бали } \\
\hline & & 5 & 3 & 0 \\
\hline $\begin{array}{l}\text { I. Вагітні з анемією, } \\
\text { n=50 }\end{array}$ & абс. \% & $\begin{array}{c}45 \\
90,0 \pm 4,24^{*}\end{array}$ & $\begin{array}{c}5 \\
10,0 \pm 4,24^{*}\end{array}$ & 0 \\
\hline $\begin{array}{l}\text { II. Вагітні } 333 \mathrm{H} \text {, } \\
\mathrm{n}=50\end{array}$ & абс. \% & $\begin{array}{c}47 \\
94,0 \pm 3,36\end{array}$ & $\begin{array}{c}3 \\
6,0 \pm 3,36\end{array}$ & 0 \\
\hline $\begin{array}{l}\text { III. Вагітні з ПГ, } \\
\text { n=50 }\end{array}$ & абс. \% & $\begin{array}{c}31 \\
62,0 \pm 6,86^{*}\end{array}$ & $\begin{array}{c}15 \\
30,0 \pm 6,48^{*}\end{array}$ & $\begin{array}{c}4 \\
8,0 \pm 3,84^{*}\end{array}$ \\
\hline $\begin{array}{l}\text { IV. KГ, } \\
n=50\end{array}$ & абс. \% & $\begin{array}{c}50 \\
100,0\end{array}$ & 0 & 0 \\
\hline
\end{tabular}

Примітка. * - p<0,05 між показниками контрольної і I, II та III груп.

| групи, 3-х випадках $((6,0 \pm 3,36) \%)$ || групи та 15 випадках $((30,0 \pm 6,48) \%)$ III групи було зареєстровано в процесі рухів неповне повернення кінцівок та тулуба в стан згинання. В 4-х випадках $((8,0 \pm 3,84) \%)$ у вагітних із ПГ зафріксовано розігнуте положення кінцівок плода. Зниження ТП, за даними А. M. Vintzileus [19], свідчить про дистрес плода та $€$ несприятливою ознакою.

У таблиці 6 продемонстровано відхилення в структурі плаценти обстежених жінок.

У жінок контрольної групи ступінь зрілості та товщина плаценти майже $((96,0 \pm 2,77) \%)$ відповідали гестаційному віку [17]. У 8 випадках $((16,0 \pm 5,18) \%)$ у вагітних 3 анемією, 9 випадках $((18,0 \pm 4,05) \%)$ у вагітних із запальними захворюваннями нирок та у 18 жінок з ПГ $((36,0 \pm 6,79) \%)$ спостерігалось передчасне старіння плаценти різного ступеня вираженості. У 3 жінок II та 8 жінок III групи зафріксовано зміни товщини плаценти, а в 1 жінки III групи реєструвалось поєднання потовщення плаценти 3 її стоншанням.

Відставання ступеня зрілості плаценти від гестаційного віку в жодній групі не виявлено.

Показники об'єму навколоплідних вод (ОНВ) представлено в таблиці 7.

Нормальні показники ОНВ зафіксовано у всіх вагітних

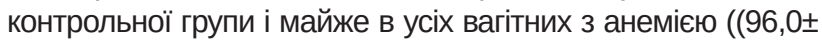
$2,77) \%)$. У вагітних із 33Н виявлена велика частота багато-

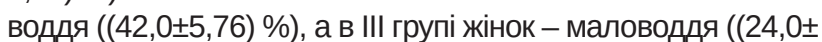
$6,04) \%)$, в тому числі значного $((8,0 \pm 3,84) \%)$. Маловоддя у жінок з ПГ, ймовірно, пов'язане з атрофрією ворсин цитотрофробласта, внаслідок чого знижується резорбція навколоплідних вод. Багатоводдя часто $є$ наслідком урогенітальної інфекції [17]. Цей фракт було доведено і нами [20].

Після вивчення кожного показника ми розрахували середній бал оцінки стану ФПК (табл. 8).

Таблиця 6. Показники структури плаценти (P士m)

\begin{tabular}{|c|c|c|c|c|c|c|c|}
\hline \multirow[t]{2}{*}{ Обстежені групи } & \multirow[t]{2}{*}{ СП } & \multicolumn{6}{|c|}{ Бали } \\
\hline & & 5 & 4 & 3 & 2 & 1 & 0 \\
\hline $\begin{array}{l}\text { I. Вагітні з анемією, } \\
\mathrm{n}=50\end{array}$ & абс. \% & $\begin{array}{c}42 \\
84,0 \pm 5,18^{*}\end{array}$ & $\begin{array}{c}6 \\
12,0 \pm 4,60 \\
\end{array}$ & $\begin{array}{c}2 \\
4,0 \pm 2,77 \\
\end{array}$ & 0 & 0 & 0 \\
\hline $\begin{array}{l}\text { II. Вагітні з 33H, } \\
\text { n=50 }\end{array}$ & абс. \% & $\begin{array}{c}38 \\
76,0 \pm 6,86^{*}\end{array}$ & $\begin{array}{c}6 \\
12,0 \pm 4,60 \\
\end{array}$ & $\begin{array}{c}3 \\
6,0 \pm 3,36 \\
\end{array}$ & $\begin{array}{c}3 \\
6,0 \pm 3,36 \\
\end{array}$ & 0 & 0 \\
\hline $\begin{array}{l}\text { III. Вагітні з ПГ, } \\
\text { n=50 }\end{array}$ & абс. \% & $\begin{array}{c}23 \\
46,0 \pm 5,95^{*}\end{array}$ & $\begin{array}{c}8 \\
16,0 \pm 5,18^{*}\end{array}$ & $\begin{array}{c}10 \\
20,0 \pm 5,66\end{array}$ & $\begin{array}{c}8 \\
16,0 \pm 5,18^{*}\end{array}$ & $\begin{array}{c}1 \\
2,0 \pm 1,41\end{array}$ & 0 \\
\hline $\begin{array}{l}\text { IV. КГ, } \\
\mathrm{n}=50\end{array}$ & абс. \% & $\begin{array}{c}48 \\
96,0 \pm 2,77 \\
\end{array}$ & $\begin{array}{c}2 \\
4,0 \pm 2,77 \\
\end{array}$ & 0 & 0 & 0 & 0 \\
\hline
\end{tabular}

Примітка. * - p<0,05 між показниками контрольної і I, II та III груп. 


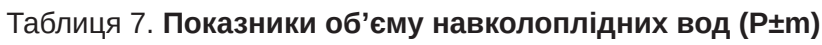

\begin{tabular}{|c|c|c|c|c|c|}
\hline \multirow{2}{*}{ Обстежені групи } & \multirow{2}{*}{ СП } & \multicolumn{4}{|c|}{ Бали } \\
\hline & & 5 & 3 & 1 & 0 \\
\hline $\begin{array}{l}\text { I. Вагітні з анемією, } \\
\mathrm{n}=50\end{array}$ & абс.\% & $\begin{array}{c}48 \\
96,0 \pm 2,77^{* \star}\end{array}$ & $\begin{array}{c}1 \\
2,0 \pm 1,41^{\star \star}\end{array}$ & $\begin{array}{c}1 \\
2,0 \pm 1,41^{\star \star}\end{array}$ & 0 \\
\hline $\begin{array}{l}\text { II. Вагітні з 33Н, } \\
\text { n=50 }\end{array}$ & абс.\% & $\begin{array}{c}23 \\
46,0 \pm 5,95^{\star}\end{array}$ & $\begin{array}{c}21 \\
42,0 \pm 5,76^{\star}\end{array}$ & $\begin{array}{c}6 \\
12,0 \pm 4,60^{*}\end{array}$ & 0 \\
\hline $\begin{array}{l}\text { III. Вагітні з ПГ, } \\
\text { n=50 }\end{array}$ & абс.\% & $\begin{array}{c}30 \\
60,0 \pm 6,48^{*}\end{array}$ & $\begin{array}{c}4 \\
8,0 \pm 3,84^{*}\end{array}$ & $\begin{array}{c}12 \\
24,0 \pm 6,04^{*}\end{array}$ & $\begin{array}{c}4 \\
8,0 \pm 3,84^{*}\end{array}$ \\
\hline $\begin{array}{l}\text { IV. KГ, } \\
\mathrm{n}=50\end{array}$ & абс.\% & $\begin{array}{c}50 \\
100,0\end{array}$ & 0 & 0 & 0 \\
\hline
\end{tabular}

Примітка. * - p<0,05 між показниками контрольної і I, II та III груп.

Таблиця 8. Середній бал оцінки стану фетоплацентарного комплексу методом ехографічного дослідження (М士m)

\begin{tabular}{|l|c|}
\hline \multicolumn{1}{|c|}{ Обстежувані групи } & Середній бал \\
\hline I. Вагітні з анемією, $\mathrm{n}=50$ & $4,71 \pm 0,16^{\star \star}$ \\
\hline II. Вагітні з запальними захворюваннями нирок, $\mathrm{n}=50$ & $4,48 \pm 0,18^{\star \star}$ \\
\hline III. Вагітні з пізнім гестозом, $\mathrm{n}=50$ & $3,82 \pm 0,19^{\star \star \star}$ \\
\hline IV. Контрольна група, $\mathrm{n}=50$ & $4,98 \pm 0,02$ \\
\hline
\end{tabular}

Примітка. ** - p<0,01, *** - p<0,001 між показниками в контрольній і I, II та III групах.

Визначені зміни не є діагнозом, це маркери динамічного стану, і показники можуть змінюватись у той чи інший бік у разі ПД. За фрормування і прогресування ФПН ці показники можуть різко змінюватись в негативний бік і мати незворотний характер.

ВисновКИ. 1. Аналізуючи дані дослідження стану ФПК за методикою ехограсрії можна простежити наявність прогресивного погіршення стану ФПК у жінок групи високого ризику розвитку пд.

2. Показники середнього бала оцінки стану ФПК, за класифрікацією І. С. Сидорової, І. О. Макарова [1], свідчать про розвиток компенсованої фрорми ФПК у

\section{СПИСОК ЛІТЕРАТУРИ}

1. Сидорова И. С. Фетоплацентарная недостаточность. Клинико-диагностические аспекты / И. С. Сидорова, И. О. Макаров. - М. : Знание-М, 2000. - 127 с.

2. Радзинский В. Е. Акушерская агрессия / В. Е. Радзинский. - М. : Изд-во журнала Status Presens, 2017. - 872 с.

3. Невідкладні стани в акушерській практиці : практичне керівництво / А. І. Сенчук, В. Х. Гінзбург, І. І. Чермак [та ін.]. - К. : Видавництво «Фенікс», 2019. - 336 с.

4. Brosens I. Placental bed research: I. The placental bed: from spiral arteries remodeling to the great obstetrical syndromes / I. Brosens, P. Puttemans, G. Benagiano // Am. J. Obstet. Gynecol. - 2019. - Vol. 221, No. 5. - P. 437-456.

5. Burton G. J. Placental origins of chronic disease / G. J. Burton, A. L. Fowden, K. L. Thornburg // Physiol. Rev. 2016. - Vol. 96, No. 4. - P. 1509-1565.

6. Липатов І. С. Патогенетичні механізми фрормування плацентарної недостатності і прееклампсії / І. С. Липатов, Ю. В. Тезіков, О. І. Лінева // Акушерство і гінекологія. - 2017. - № 9. - С. 64-76.

7. Макацария А. Д. Беременность высокого риска / А. Д. Макацария, Ф. А. Червенака, В. О. Бицадзе. - М. : Медицинское информационное агентство, 2015. - 920 с.

8. Placental lake in high-risk pregnancy / D. Bursac, жінок, вагітність яких ускладнюється запальними захворюваннями нирок, та тенденцію до субкомпенсації у разі ускладнення вагітності пізнім гестозом.

3. Категорія пацієнток із виявленими ехографрічними ознаками порушень ФПК потребує ретельнішого спостереження і прийняття рішень залежно від терміну вагітності і прогресування ознак ФПН.

ПЕРСПЕКТИВИ ПОДАЛЬШИХ ДОСЛІДЖЕНЬ. Визначені ехографрічні порушення в системі мати-плацента-плід можна використовувати для визначення ефективності медикаментозної корекції виявлених фрункціональних порушень.

V. Madzarac, V. Kardum [et al.] // Z. Geburtshilfe Neonatol. 2014. - Vol. 218, No. 1. - P. 43-44.

9. Bowman C. E. Regulation of maternal-fetal metabolic communication / C. E. Bowman, Z. Arany, M. J. Wolfgang // Cell Mol. Life Sci. - 2021. - Vol. 78, No. 4. - P. 1455-1486.

10. Pre-eclampsia part 1: current understanding of its pathophysiology / T. Chaiworapongsa, P. Chaemsaithong, L. Yeo, R. Romero // Nat. Rev. Nephrol. - 2014. - Vol. 10, No. 8. - P. 466-480.

11. Holness N. High-risk pregnancy / N. Holness // Nurs. Clin. North Am. - 2018. - Vol. 53, No. 2. - P. 241-251.

12. Hladunewich M. A. Chronic kidney disease and pregnancy / V. A. Hladunewich // Semin. Nephrol. - 2017. - Vol. 37, N 4. - P. 337-346.

13. Preeclampsia: updates in pathogenesis, definitions, and guidelines / E. Phipps, D. Prasanna, W. Brima, B. Jim // Clin. J. Am. Soc. Nephrol. - 2016. - Vol. 11, No. 6. - P. 1102-1113.

14. Horowitz K. M. Anemia in pregnancy / K. M. Horowitz, C. J. Ingardia, A. F. Borgida // Clin. Lab. Med. - 2013. - Vol. 33, No. 2. - P. 281-291.

15. Antza C. Hypertensive complications of pregnancy: A clinical overview. C. Antza, R. Cifkova, V. Kotsis // Metabolism. - 2018. -Vol. 86. - P. 102-111. 
16. Оценка и мониторинг жизнедеятельности плода / ред. Кертис Л. Бейсингер, Бренда А. Баклин, Дэвид Р. Гэмблинг, М. Дж. Ричардсон, М. Димичели-Зигмонд // Практическая акушерская анестезиология. - 2-е изд. - М. : ООО «Медицинское инфрормационное агентство», 2020. - С. 115-141.

17. Ультразвуковая диагностика в акушерстве и гинекологии : в 2 т. / Эберхард Мерц ; пер. с англ. ; под общ. ред. профр. А. И. Гуса. - М. : МЕДпресс-инсрорм, 2011. - Т. 1 Акушерство. -720 с.

18. Мэнинг Ф.А.Глава 26. Оценка биосизического профриля плода: теоретические предпосылки и практическое применение // Эхография в акушерстве и гинекологии. Теория и практика. 6-е изд. В II частях. Часть вторая / под ред. А. Флейшера, Ф. Мєнинга, П. Дженти, Р. Ромеро ; пер. с англ. - М. : Изд. Дом Видар-М, 2004. - С. 41-51.

19. The fetal biophysical profile and its predictive value / A. M. Vintzileos, W. A. Campbell, C. J. Ingardia, D. J. Nochimson // Obstet. Gynec. - 1983. - Vol. 62. - P. 271-274.

20. Безопасное материнство: подготовка, беременность, роды, послеродовый период : руководство для практикующих врачей / под ред. А. Я. Сенчука, И. И. Чермака [и др.]. - Минск : Профрессиональные издания, 2021. - 216 с.

\section{REFERENCES}

1. Sidorova, I.S. \& Makarov, I.O. (2000). Fetoplatsentarnaya nedostatochnost. Kliniko-diagnosticheskiye aspekty [Fetoplacental insufficiency. Clinical and diagnostic aspects] Moscow: Znaniye-M [in Russian]

2. Radzinskii, V.E. (2017). Akusherskaya agressiya v. 2.0 [Obstetric aggression v. 2.0]. Moscow: StatusPraesens [in Russian].

3. Senchuk, A.la., Hinzburh, V.H., \& Chermak, I.I. (2019). Nevidkladni stany $v$ akusherskii praktytsi: praktychne kerivnytstvo [Emergencies in obstetric practice: a practical guide]. Kyiv: Fenix [in Ukrainian]

4. Brosens, I., Puttemans, P., \& Benagiano, G. (2019). Placental bed research: I. The placental bed: from spiral arteries remodeling to the great obstetrical syndromes. American Journal of Obstetrics and Gynecology, 221 (5), 437-456.

5. Burton, G.J., Fowden, A.L., \& Thornburg, K.L. (2016). Placental origins of chronic disease. Physiological Reviews, 96 (4), 1509-1565

6. Lipatov, I.S., Tezikov, Yu.V., \& Linev, O.I. (2017). Patogeneticheskie mekhanizmy formirovaniya platsentarno nedostatochnosti i preeklampsii [Pathogenetic mechanisms of placental insufficiency and preeclampsia]. Akusherstvo $i$ ginekologiya - Obstetrics and Gynecology, 9, 64-76 [in Russian]

7. Makatsariya, A.D., Chervenaka, F.A., \& Bitsadze, V.O. (2015). Beremennost vysokogo riska [High risk pregnancy]. Moscow: Meditsinskoye informatsionnoe agentstvo [in Russian].

8. Bursac, D., Madzarac, V., Kardum, V., Skrtic, A., Kulas, T., \& Hrgovic, Z. (2014). Placental lake in high-risk pregnancy. Zeitschrift für Geburtshilfe und Neonatologie, 218 (1), 43-44.

9. Bowman, C. E., Arany, Z., \& Wolfgang, M. J. (2021). Regulation of maternal-fetal metabolic communication. Cellular and Molecular Life Sciences, 78 (4), 1455-1486.

10. Chaiworapongsa, T., Chaemsaithong, P., Yeo, L., \& Romero, R. (2014). Pre-eclampsia part 1: current understanding of its pathophysiology. Nature Reviews Nephrology, 10 (8), 466-480.

11. Holness, N. (2018). High-risk pregnancy. Nursing Clinics, 53(2), 241-251.

12. Hladunewich, M.A. (2017). Chronic kidney disease and pregnancy. Seminars in Nephrology, 37 (4), 337-346.
13. Phipps, E., Prasanna, D., Brima, W., \& Jim, B. (2016). Preeclampsia: updates in pathogenesis, definitions, and guidelines. Clinical Journal of the American Society of Nephrology, 11 (6), 1102-1113.

14. Horowitz, K.M., Ingardia, C.J., \& Borgida, A.F. (2013). Anemia in pregnancy. Clinics in Laboratory Medicine, 33 (2), 281-291.

15. Antza, C., Cifkova, R., \& Kotsis, V. (2018). Hypertensive complications of pregnancy: a clinical overview. Metabolism, 86. 102-111.

16. Richardson, M.Dzh., Dimicheli-Zigmond, M., \& Gembling, D.R. (2020). Otsenka i monitoring zhiznedeyatelnosti ploda // Prakticheskaya akusherskaya anesteziologiya [Assessment and monitoring of fetal activity // Practical obstetric anesthesiology]. Moscow: OOO «Meditsinskoye informatsionnoye agentstvo» [in Russian].

17. Hus, A.Y. (2011). Ultrazvukovaya diagnostika $v$ akusherstve i ginekologii: $v 2$ t. [Ultrasound diagnostics in obstetrics and gynecology: in 2 volumes]. Moscow: MEDpressinform [in Russian].

18. Fleyshera, A., Manning, F.A., Dzhenti, P., \& Romero, R. (2004). Glava 26. Otsenka biofizicheskogo profilya ploda: teoreticheskiye predposylki i prakticheskoye primeneniye /I Ekhografiya $v$ akusherstve i gineklogii. Teoriya i praktika. 6-ye izd. V II chastyakh. Chast vtoraya [Assessment of the biophysical profile of the fetus: theoretical background and practical application // Echography in obstetrics and gynecology. Theory and practice. 6th ed. In the II parts. Part two]. Moscow: Izd. Dom Vidar-M [in Russian].

19. Vintzileos, A.M., Campbell, W.A., Ingardia, C.J., \& Nochimson, D.J. (1983). The fetal biophysical profile and its predictive value. Obstet. Gynec., 62, 271-274.

20. Senchuk, A.Ya., \& Chermak, I.I. (2021). Bezopasnoye materinstvo: podgotovka, beremennost, rody, poslerodovyy period: rukovodstvo dlya praktikuyushchikh vrachey [Safe motherhood: preparation, pregnancy, childbirth, the postpartum period: a guide for practitioners]. Minsk: Professionalnyye izdaniya [in Russian].

Отримано 09.04.21

Прийнято до друку 11.05.21 Електронна адреса для листування: 0509453723@ukr.net 